\title{
ELECTROPHORETIC STUDIES OF EGG WHITE PROTEINS
}

\author{
$B y$
}

*H.M. Salem, A.M. Youssha and A.R. El-Harra,

\begin{abstract}
Paper elintrophoresis tochnique was used for the snelysis of egg whito proteing of different birds belonging to different phylogevetio order:, Throo hen rarietice i.e. Rhodo Island, Balady aud Fayoumi showed 9 protein bands. Difforent apocies such as Turkey, Sudaniduels, Fokin dvek and goose showed only 8 protein bsinds.

The soluble proteins of tho Rhod: Island ogg white was aubjected to extensive anslysig. I)ifferent fractions wero obtained when different concentrations of smm. sulphste were used in separarion. Ovalbumius showod 4 protein components, colalbugip was represerted by one bond while ovomucoid contaised $\sigma$ bandt 0 verlajped with thoos of ovalbumin. Globulin was separated to 3 fractiosia $\mathrm{G}_{1}, \mathrm{G}_{2}$ and $\mathrm{G}_{2}$. A new fraction was separated at $60 \%$ amm. oulphate astu- ration and was fractionated inio 3 bonds.
\end{abstract}

For a long time egg proteins were consideerd important constituents of the human diet. This should be true in imperative since the egg must provide all the essential nutrients for the emberyonic development of the chick to the stage when oral nutrition becomes possible.

Bain and Deutsch (1948), presented the electrophoretic diagram cou. vering the examination of egg white proteins of 13 species of birds belonging to 6 different phylogenetic orders. A characteristic pattern was obtained for each species. It was possible to differentiate each species by this technique.

Lewis ot al. (1048), studied the electropforetic pattern of egg white. Their pattern indicated 7 distinguishable components, ovalbumin $\mathbf{A}_{1}$ and

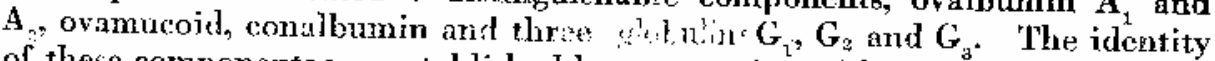
of these components was established by comparsion with the pattern obtained from the purified components witl the exception of the globulins.

The ohject of this investigation was the study of the protein components of egry of differut species in U.A.R. and an attempt of sonaration and identification of these proteins was performed.

\footnotetext{
*Biochemistry Division, Animal Production Departmont, Faculty of Agriculturo, Cairo
University, Giza.
} 


\section{Materials and Mothods}

In this study hen eggs of different varieties were used. These included the Balady, Fayoumi and Rhode Island. Eggs of different species belonging to different phylogenetic orders such as, Turkey, Sudani duck, Pekin Duck and Goose were also used. Egg samples were provided by the HigherAgxicultural Institute Poultry Farm at Kafr-el-Sheikh.

\section{Preparation of egg white proteins for paper electrophoresis :}

Egg whites were separated from the egg yolk and chalazae, then homogenized by stirring. Pyridine-glacial acetic acid buffer solution was prepared $(8 \mathrm{ml}$. pyridine, $2.5 \mathrm{ml}$. gl. acetic acid per litre of distilled water), then adjusted to $\mathrm{PH}$ 5.5. Egg white was diluted with the buffer solution in the ratio of $1: 3 \mathrm{~V} / \mathrm{V}$ and the mixture was centrifuged at 3500 r.p.m. The precipitate containing the insoluble impurities was discarded, while the gupernatant solution containing the soluble proteins was subjected to paper electrophoresis.

\section{Paper electrophoresis techrique :}

Methods described by Durrum (1950) were used utilizing pyridine acetic acid buffer ( $\mathrm{pH}$ 5.5), Whattmann No. 1 filter paper strips and lasting for 16 hours under 220 volt.

After complete separation the strips were removed and the protein bands were localized after staining with azo-carmen $B$ dye.

Quantitative determination of the protein bands :

The localized protein bands were estimated by a model MGE Berlin densitometer. The colour density of each pattern was recorded on a paper strip in the shape of a curve. The curve was divided into areas under each peak. Each area relative to the total area was measured by means of a planimenter. From these measurments the relative percentage of each protein was detemined as shown in figs. : $1,3,5,7,9,11,13$ and 15 .

\section{Fractionation Methods :}

Different methods were applied for the separation of the different protein constitutions of the Rhode Island egg whites which were localized in the electrophoretic pattern.

These methods were as follows :

\section{1.-Precipitation with Ammonium sulphate :}

An aliquot $(50 \mathrm{mI}$.) of the egg white solution in the pyridine / acetic buffer $\mathrm{pH} 5.5$ was cooled to ${ }^{10} \mathrm{C}$. A cooled saturated amfonium sulphate solution was gradually added until a turbid was occurred. The mixture was 
then left in the cold for an hour until a precipitate was formed. The mixture was centrifuged, the precipitated proteins were redissolved, diluted to $50 \mathrm{ml}$. with the buffer, then dialyzed against the same buffer and subjected to paper electrophoresis. The supernatant was filtered off and retained for further fractionation of the other protein components by the addition of saturated amm. sulphate solution in the same manner. Fractionation proceeded until no precipitate could be obtained.

\section{2.--Heat fractionation technique :}

The buffered egg white solution was heated to $100^{\circ} \mathrm{C}$. on a water bath for 4 hrs. The mixture was centrifuged and the precipitate was discarded. The supernatant after filtration was subjected to paper electrophoresis.

\section{3.- Cold acetone or cold alcohol precipitation :}

This technique was applied for the separation of different protein constituents of ovomucoid fraction. The buffered protein solution ( $50 \mathrm{ml}$.) was cooled to $1^{\circ} \mathrm{C}$., then cold acetone or ethanol was added dropwise. The precipitate when formed was centrifuged, redissolved, diluted to $50 \mathrm{ml}$. with the pyridine buffer and subjected to electrophoresis. The supernatant was filtered of and retained for fractionation of the other protein components using further addions of cold acetone or alcohol in the same manner until no precipitate could be obtained.

\section{4.-Dialysis techique :}

This method was applied for the separation of egg white globuline. Whole egg white was dialyzed againat distilled water. A precipitate was formed. The mixture was centrifuged and the precipitate was dissolved in pyridine acetic buffer ( $\mathrm{pH}$ 4.0). The solution was filtered, then subjected to paper electrophoreais.

\section{5.-Column chromatography fractionation technique :}

This method was used for the separation of the components of ovalbumin and ovomucoid. An ionic exchange column of carboxymethyl cellulose (CMC) was used. Two starting phosphate buffers with different concentration were used. The first was $\mathrm{NaHPO}_{4}+\mathrm{NaH}_{2} \mathrm{PO}_{4} 0.01 \mathrm{M}$ at $\mathrm{PH} 6.0$.

The higher concentration was $0.1 \mathrm{M}$ at the same $\mathrm{pH}$.

\section{Revults}

Fractions of Egg white Proteins :

1.-Ovalbumin :

The fraction obatined at $52 \%$ amm. sulphate saturation was electrophoretically similar to the ovalbumin fraction which was prepared according to the method of Srensen and Hyrup (1950). This fraction indicated tho 
presence of four bands in the electrophoretic analysis. They were represented as the bands $1,2,3$, and 4 , in the original egg wite pattern fig. 15. These four bands were separated from each other by using column chromatography technique as shown in figs, 16 to 21 .

\section{2.-Conalbumin :}

The fraction obtained at $57 \%$ amm. sulphate saturation was electrophoretically represented by the bind number $8 \mathrm{fig}$. 22 . This fraction was found to be similar to conallumin which was prepared by alcohol fractionation technique according to Bain and Deutsch (1948).

\section{3.--Unknown fraction.}

A fraction indicating electrophoretically the presence of three bands represented as 5,6 , and 7 on the original elcetrophoretic pattern was obtained at $60 \%$ amm. sulphate saturation fig. 23 .

\section{4.- Ovomucoid :}

The fraction obtained at $65 \%$ am. sulphate saturation was found elctrophoretically similar to the non-coagulable protein known as ovomucoid which was prepared according to Hesselvik (1938), by heat coagulation. The electrophoretic analysis of this fraction revealed the presence of five bands a? shown in fig. 24.

The firs four bunds of ovonucoid were also otbtained as a fraction at $70 \%$ ethyl alcohol soncertration, while the fifth band was obtained by $80 \%$ acetono concentration fig. 25. CMC. Columis chromatography was ueed

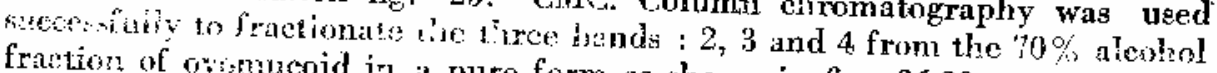
fraction of owsmucoid in a pure form as shown in figs. 26.29 .

\section{5.-Globulins :}

This fraction was found to contain three proteins, and was elctrophoretically identified as that fraction known as globulins $G_{\tau}, G_{2}$ and $G_{3}$ which (1945).

The first $G_{i}$ was obtained when $15-20 \%$ ethanol concentration was used as represented by band 9 in the original electrophoretic pattern fig. 30.

The second globulin $\mathrm{G}_{2}$ was obtained at $37 \%$ amm. sulphate saturation fig. 32 , while $G$ was obtained at $47 \%$ amm. sulphate saturation. The two against water and the formed precipitaten the whole egg white was dialyzed buffer at PH 4.0.

U.A.R. J. Anim. Prod., 11, No. 1 (1971). 

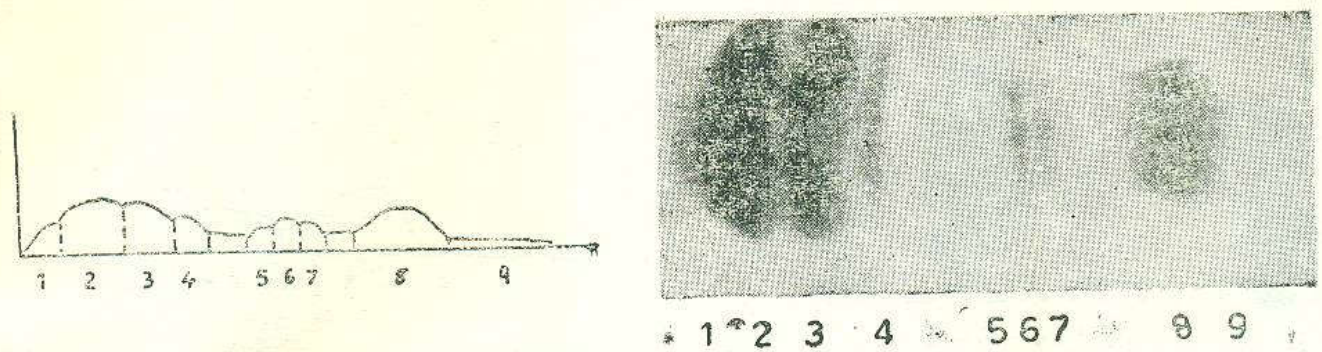

FrG. 1

Rhode Island

Fig. 2
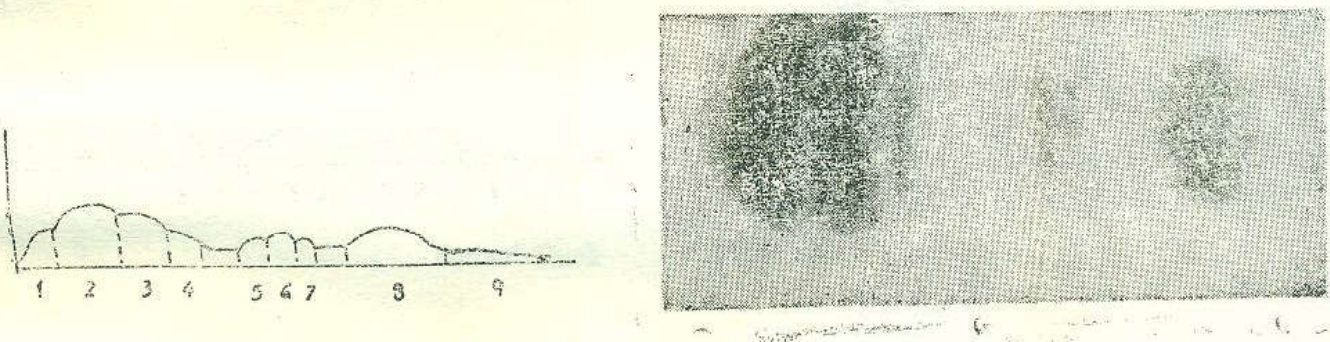

FIG. 3

Tayoumi

Fig. 4
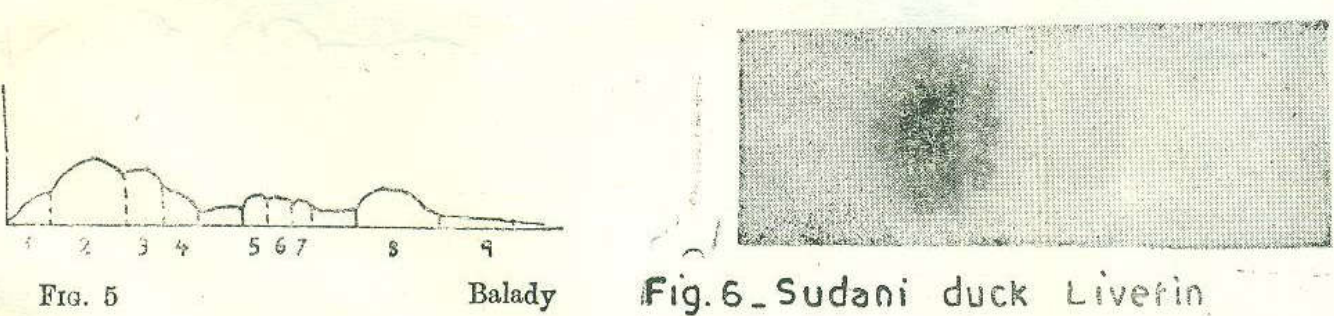

Fig.6_Sudani duck Liverin

Electrophoretic curves and patterns of egg white proteins (Pyr:dine - acetic buffer pH 5.5)

U.A.R. J. Anim. Prod., 11, No. 1 (1971). 


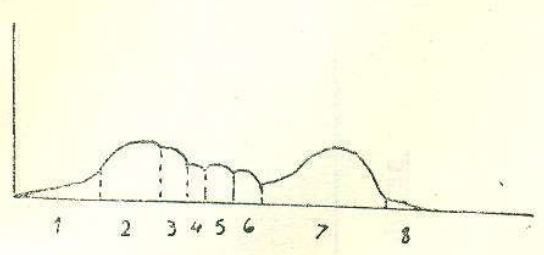

FIQ. 7

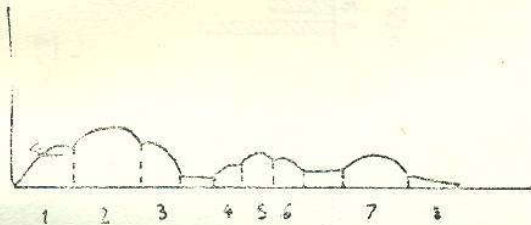

Fio. 8

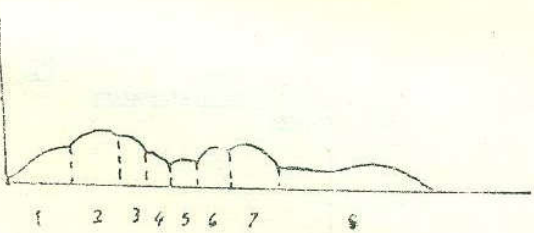

FI: 11

Pekini Duck

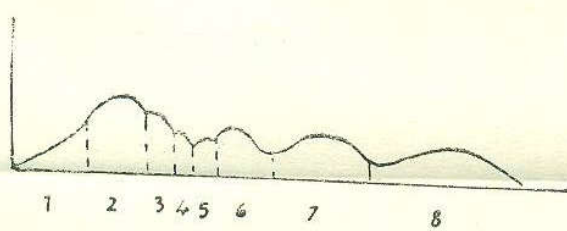

FIa. 13
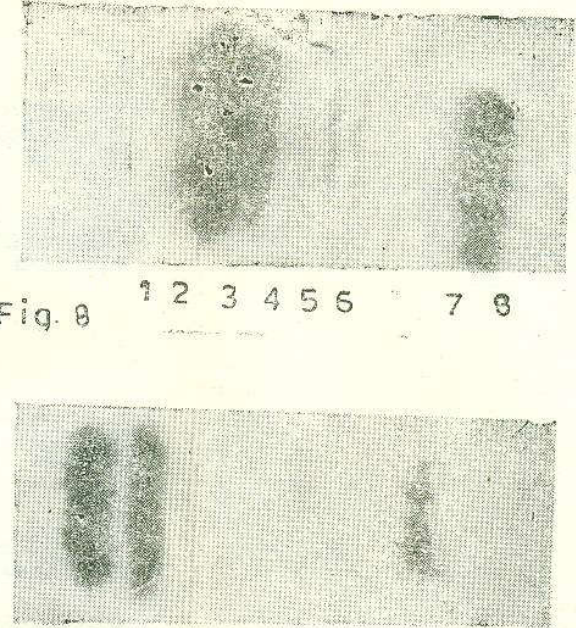

Fig. 10

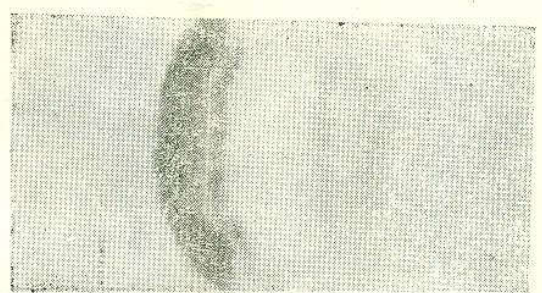

Fig. 12

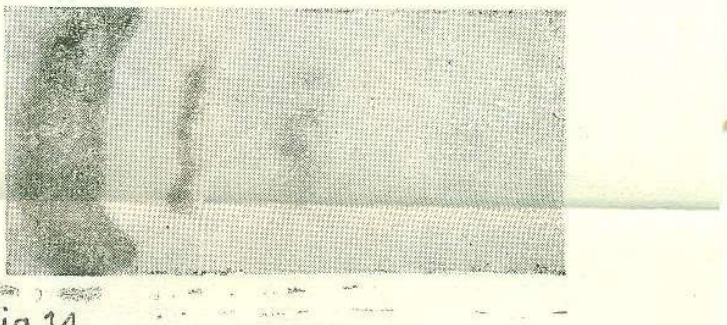

Fig. 14

Electrophorie patterns 8 curves of erg white of different birds

U.A.R. J. Anim. Prod., 11, No. 1 (1971). 


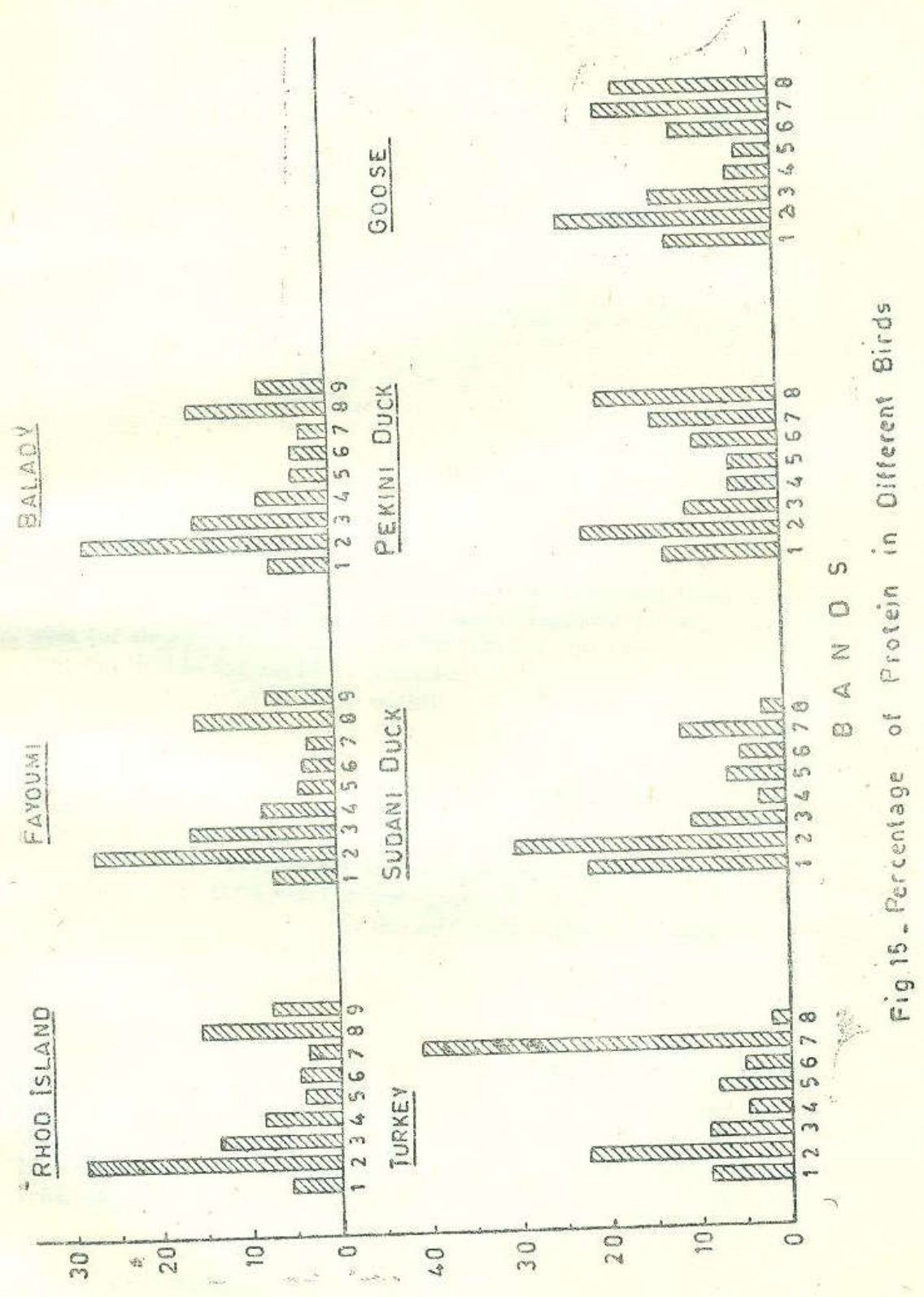

U.A.R. J. Anim. Prod., 11, No. 1 (1971). 
1234

)

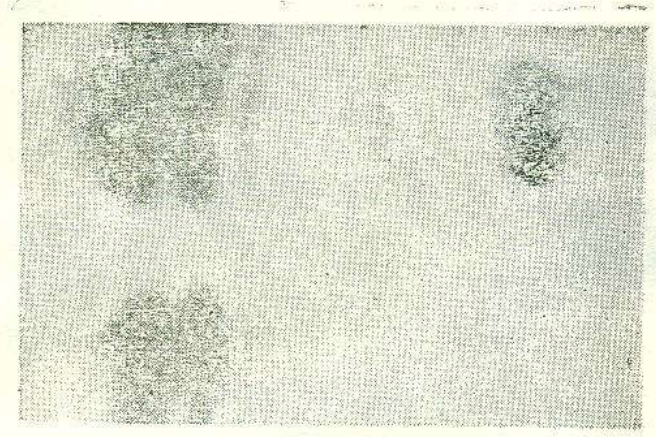

1234

Fic. 16-3ilectrophoretic pattern of :

(a) Hen egg white (b) Ovalbumin fractions. (Separated at $52 \%$ Amm. Sulphste Saturation)

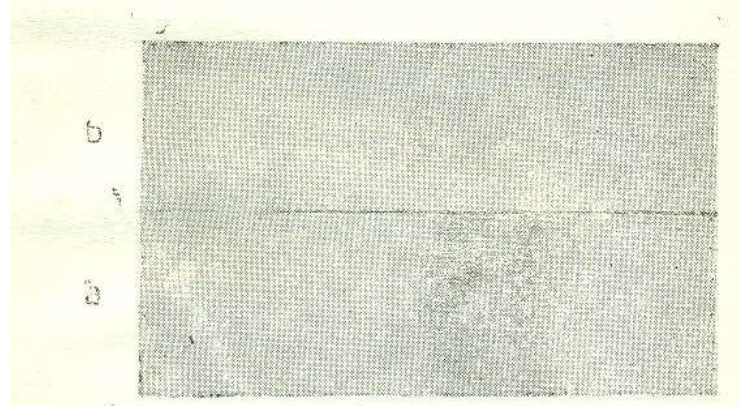

Fig. 18-Band 1

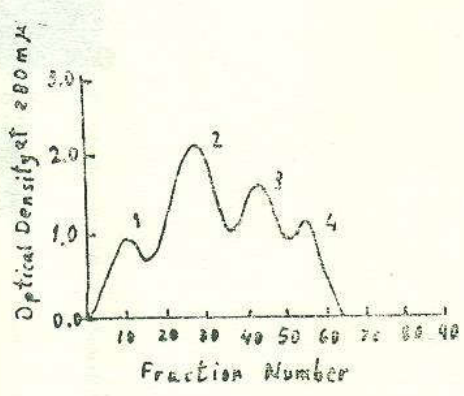

FIG. 17-Ovalbumin curve

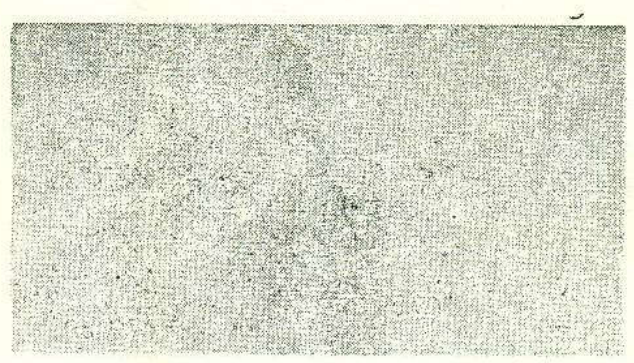

Fig. 19-Band 2

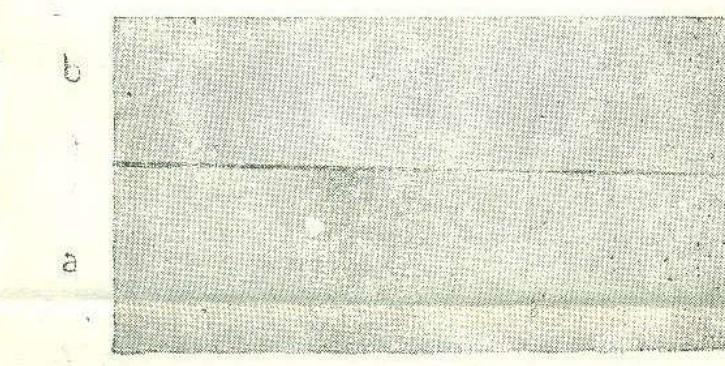

Fig. 20 -Band 3

Electrophoretic patterns of ovalbumin fracticns.

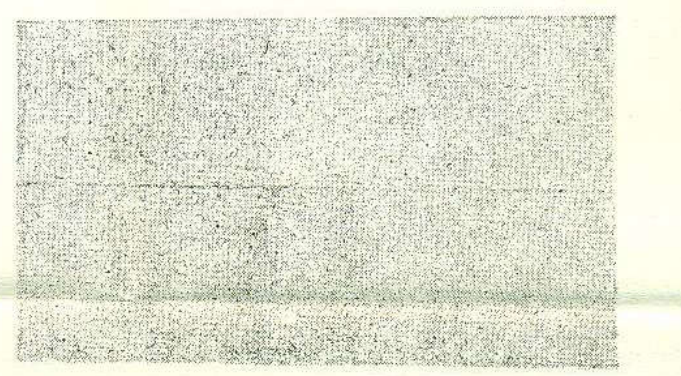

Fig. 21 -Band 4

D.A.R. J. Anim, Prod., 11, No. 1 (1971). 


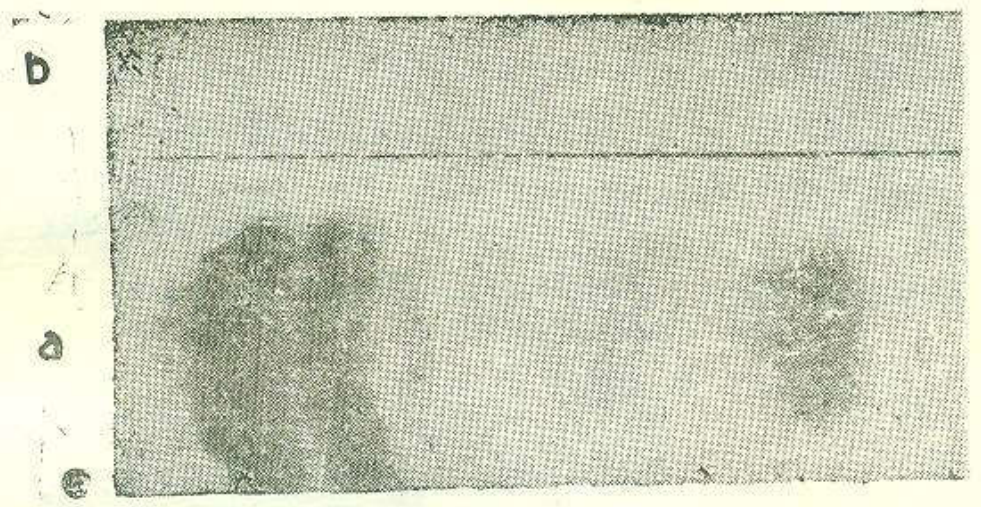

FIG. 22-Electrophoretic pattern of :

(a) Hen egg white

(b) Conalbumin fraction (Separated at $57 \%$ amm. Sulphate saturation).

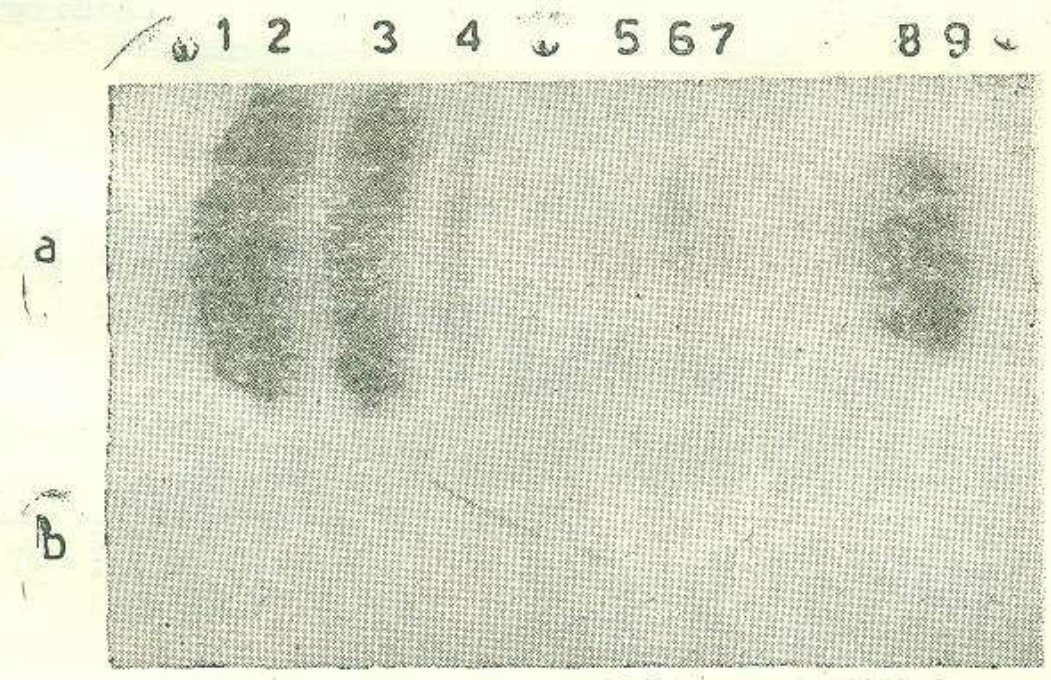

FIG, 23-Electrophoretic pattean of :

(a) Hen egg white

(b) Un known fraction $(5,6,7)$ separated at $60 \mathrm{amm}$. Sulphate saturation. 


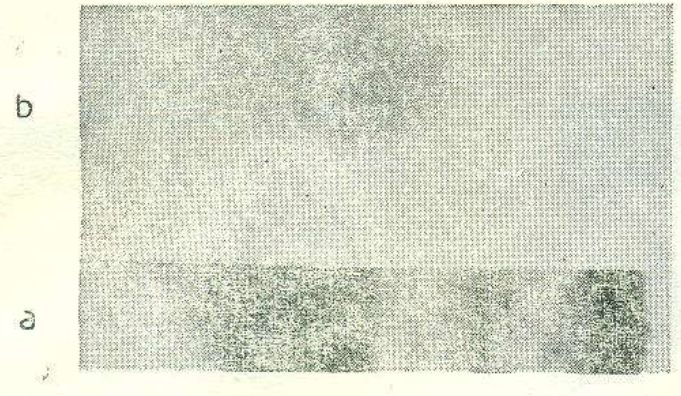

FIG 24-Electrophoretic pattern of :

(a) Fen egg white

(b) Non-coagulable ovomucoid fraction (65\% amm. sulphate). b

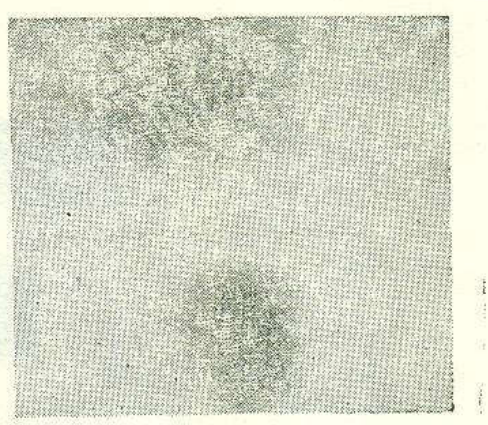

Fic. 25 -Ovomuccid Fracticus :

(x) Separated at $80 \%$ ace one Co. (b) Separated at $70 \%$ e hanol Co.

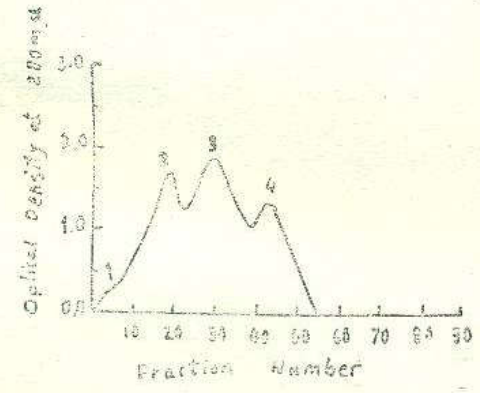

Fic. 26 -Ovemuooid. Chromatograne Curve.

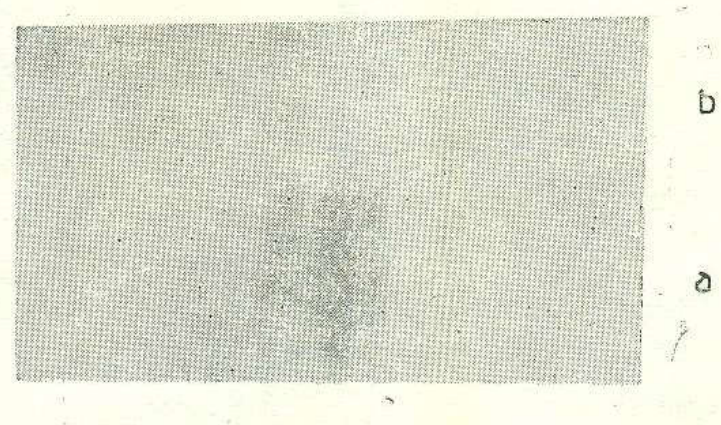

Fra. 27-Oremuooid Band 1

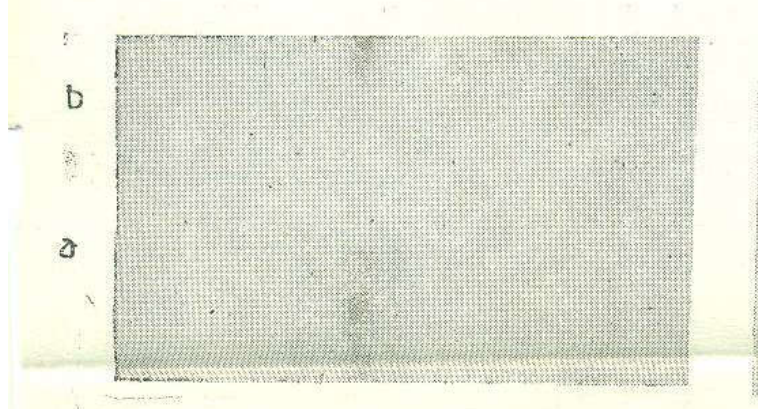

Fic. 28 - Ovomucoid Band 2

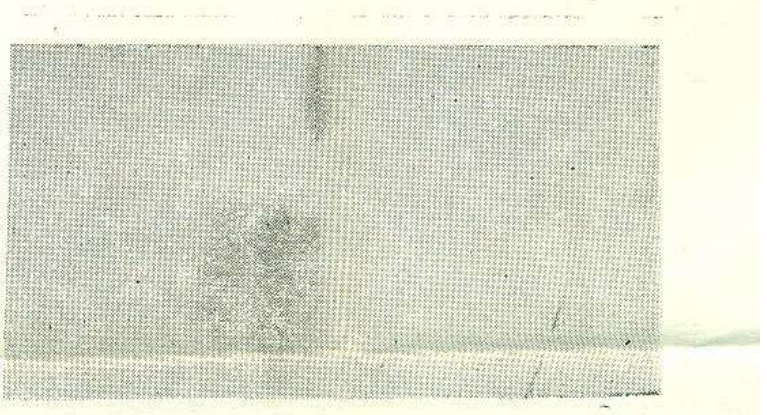

Frg. 29-0vomucoid Band 3

Eloctrophoretic Patterns of ; (a) Ovomucoid fractions. (b) Ovomucoid bands 1, 2 \& 3.

U.A.R. J. Anim. Prod., 11, No. 1 (1971). 


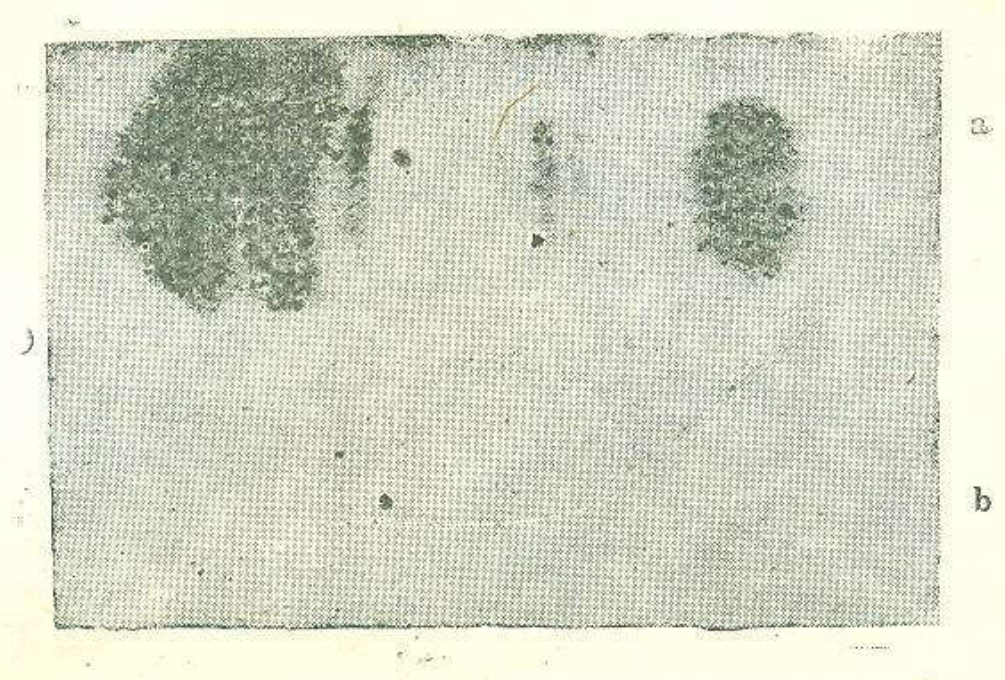

Fra. $30-$-Glubilin Fractions

(b) G I (20\% ethanol concentration)

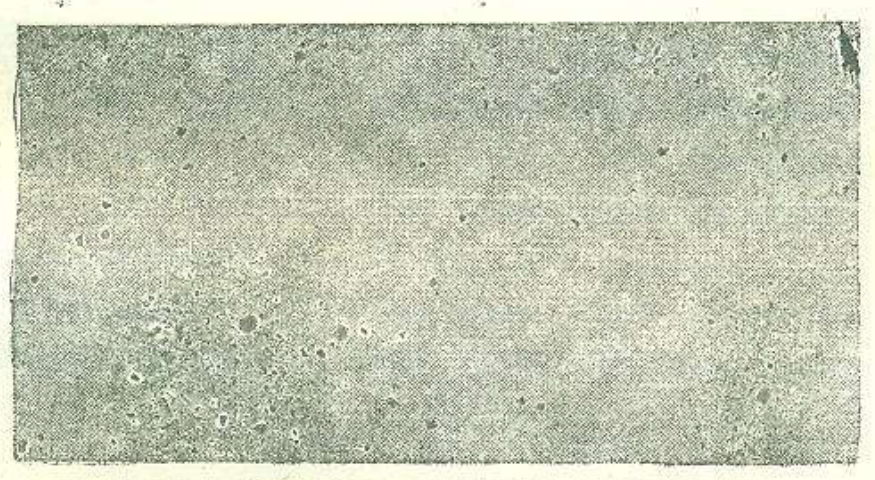

Frg. 31-Globulin Fractions

(b) G2 (38\% amm. sulphate ssturation)

Electrophoretic Patterns of :

(a) Hen egg white.

(b) Globulin fractions (G1, G2).

U.A.R. J. Anim. Prod., 11, No. 1 (1971).. 


\section{Discustion}

Although much work has been done by different workers on the egg protein constituenta and their chemical composition, no definite results wexe reported concerning their electrophoretic studies.

This work compromised an examination by paper electrophoresis of the soluble proteins of egg white. The most suitable results were obtained when a pyridine/acetic acid buffer solution at pH 5.5 was used.

The most striking fact emerged from this work was the considerable differences in the electrophoretic patterns and diagrams of either different varieties of hen or different phylogenetic orders. These differences were not merely of degree, since some quantitatively important components of the proteins found in eggs were present in some species, but completely absent from others figs I-15. Bain and Deutsch (1947), reported the same results.

The amout of each protein differs from one electrophoretic pattern to another according to the density of the dye on the paper. The densitometer was used to measure the color of the bands located on the electrophoretic patterm.

The electrophotretic patterns of the whole egg white of the three hen -varieties i.e. Rhode Island, Fayoumi and Baladi were identical in mobility having 9 distinct bands but slightly differed in the quantity.

On the other hand, the patterns obtained from Turkey, Sudani duck, Pekini duck and Goose showed only eight distinct bands with remarkable difference in quantity owing to their different phylogenetic orders figa. 1-15.

Different methods were used to separate each protein band located in the electrophoretic pattern of the Rhode Island variety in rather a pure state.

It was planned to separate the soluble proteins of the egg white using closer ranges of amm. sulphate saturations.

The fraction obtained at $52 \%$ amm. sulphate saturation was identified as ovalbumin and was fonnd to contain four protein bands $1-4$ fig. 2 . Separation of the four components were achieved by using the ion exchange column chromatography, then followed by the electrophoretic analysis figa 17-21. These results disagreed with those reported by Lewis et al. (1948), who postulated the presence of only two components. Other workers (5), (12) reported the presence of three components. These differences in results might be due to th different buffers uged or to the different techniques applied 
The fraction represented as band 8 fig. 22 was identified as conalbumin. It might be concluded that conalbumin could be obtained at $57 \%$ amm. sulphate saturation. This result agreed with those obtained by Clark et al. (1963) and Hellhammer et al. (1958).

The fraction obtained at $65 \%$ amm. sulphate saturation was identified as the non-coagulable ovomucoid protein. This fraction when subjected to column ehromatography then followed by electrophorctic analysis was found to contain five components. Ovalbumin and 0vomucoid were overlaped by each other since the five bands of ovomucoid were found on the same place where the ovalbumin usually migrates on the paper fig. 24-29. This may be due to the fact that in an electric field a protein moves at a rate determined by the size and shape of the molecule and by the number and kind of jonizied groups. Fractions that appear homogeneous by criterion of solubility may contain components that differ in rate of electrophoretic travel.

These resulte differed from those obtained by earlier investigators $(6$, 10,12 ) who indicated electrophoretically the presence of one or two components.

A fraction obtained at $60 \%$ amm. sulphate saturation was separated elcelrophoretically into three bands fig. 23 . These bands 5,6 and 7 were not identified by any other investigators.

The fractions obtained by $20 \%$ ethanuol concentration or at $38 \%$ and $47 \%$ amm. sulphate saturation were identified as the globulins $G_{1}, G_{2}$. and $G_{3}, G_{1}$ showed the highest mobility of all egg white proteins representing band 9 . The other two $G_{2}$ and $G_{3}$ were ovrlaped by the preeceding bands 7 and 8 . These bands were previously identified by Longsworth et al, (1940).

\section{REFERENCES}

ALdezton, G., WARD, W.H., AND FrvoLd, H.L.-Isolation of lyeozoyme from egg white. J. Biol. Chem. 15t, 43 (1945).

BAIX, J.A., AND DEUTSCr, H.F,-An eleotrophoretic study on the egg white proteind of varion. birds. J. Biol. Chem., 17I, Б̇31-4l (1974).

- - - Separation and oharacterization of consibumin. Ibsd, 17z, 247 (1948).

Clak, J.R., Osugs, D.T., AND Ferns, R.E.-Composition of avian egg white conalbuming., J. Biol. Chem., 938, 11, 3621 (1963).

Dorrum, E.L.-A microelectrophoretic and microionophoretic tochnique, J. Am. Chem. Soc., T\%, 2943-48 (1950).

Evars, R.J.,AND BANDTMEl, S.L.-Separation of egg white proteir a by paper electrophoreeis. J. Agr. Food Chem., 4, 80210 (1956).

FoвsYtre, R.H., A $\mathrm{WD}$ Foster, 9.F.-Electropohoretic atadies on whole egg white. J. Biol. Chem., 184, 377-83 $\{1950)$.

U.A.R. J. Anim. Prod., 11, No. 1 (1971). 
Hexilammik, D., and Hogr, 0.-Paper electrophoregis of egg proteins. MitT Gebrita LE JGNSON. U. Hyg., 49, 165-71 (1958); 50, 84-110 (1959). (o.f from Chem. Abe., B3, 491,26367 1959).

Hesselvik, L,-Z. Physiol. Chetr, 254, 144 1938); o.f from Advances in proiein Chem. Vol. VI, 188. 1950\%.

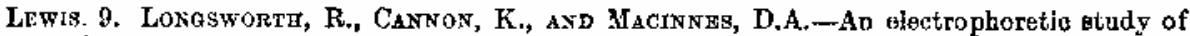
the protoins of egg white. $J$. Am. Chem. Soc., r0, 2580-89 1948).

Longsworth, L.G., Cannon, K., AND Macinses, D.A.; -An electrophoeratio study of the protein of egg white. J. An. Chem. Soc., 6?, 705-11 1940).

Sorengon, S.P., aND HoxruP, H.-Compt. rend. trav. lab. Carlesberg, 12, 167. o.f from Advances in protein Chemistry vol. VI, 188 (1950).

Sueske, H.--Electrophoretic etudies of chick agg whito and process of its fractionation by sodium sulphate. Seiutza Butouri Kayaka. 1, 41-45 1952). e.f. from Chem. Abs., 51 8836 (1057).

Sugano, B.-Electrophoretic studiea on proteins. Hen egg white. J, Fac. Scs. Nugafa Unin. Ser., 1, 2, 31-38. o.f from Chem. Abs., 49, 14069 ;1955). 


\section{دراسة عن بروتينات بياض البيض بطريقة التقريد الكهربى}

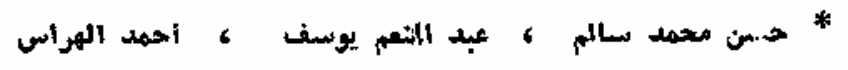

\section{1لالنغص}

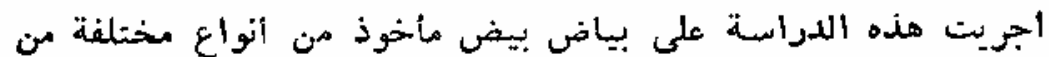

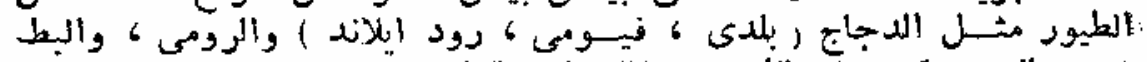

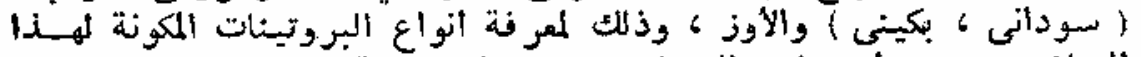

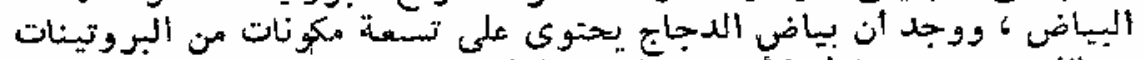

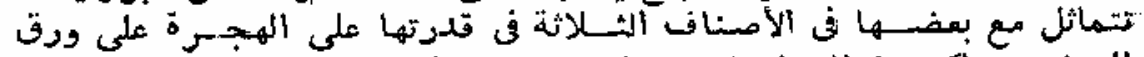

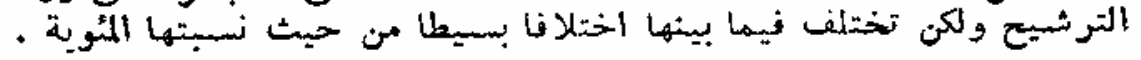

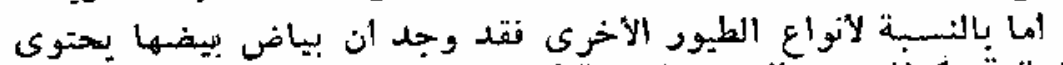

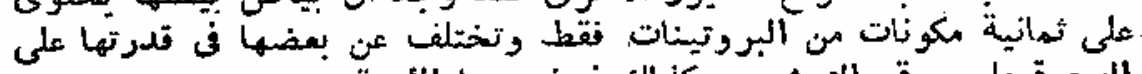

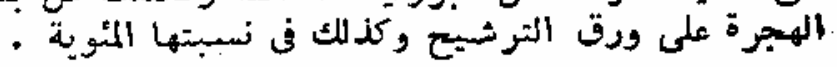

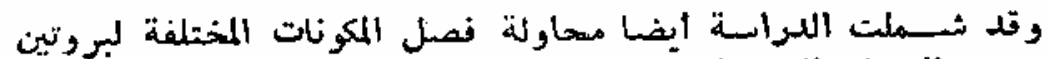

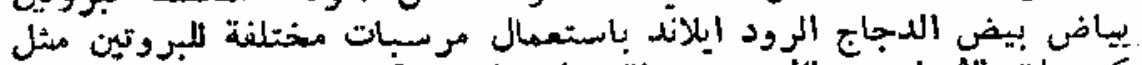

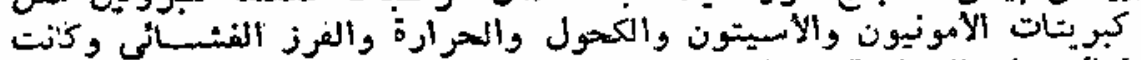

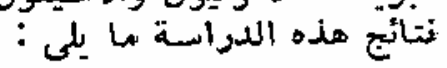

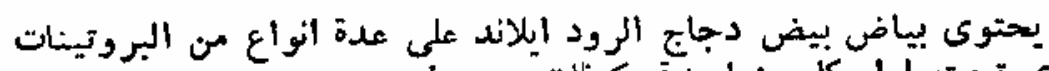

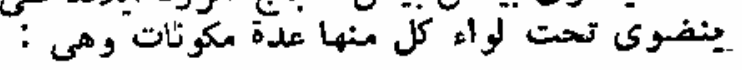

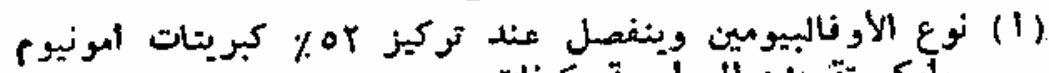

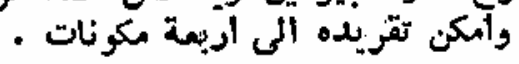

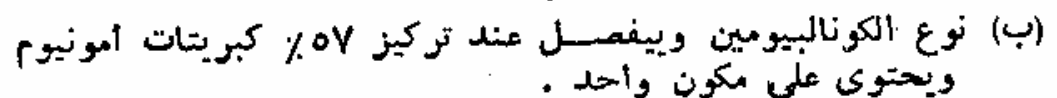

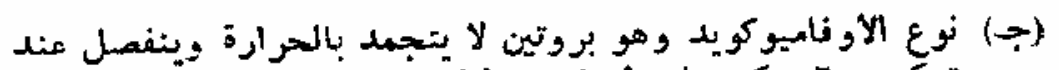

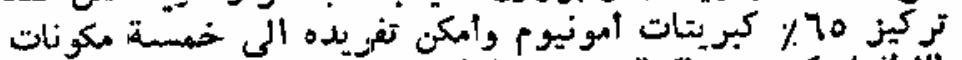

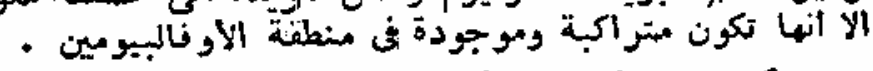

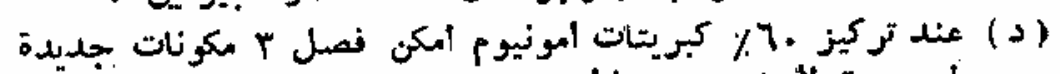

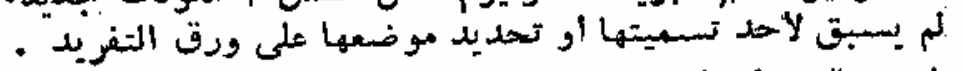

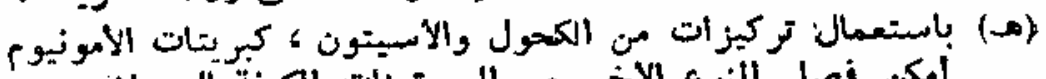

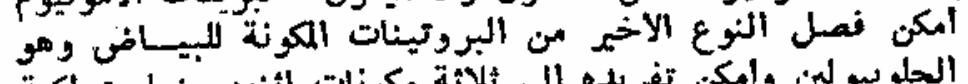

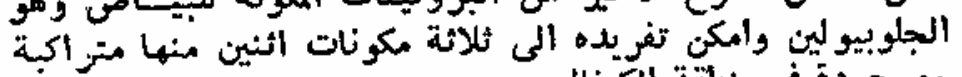

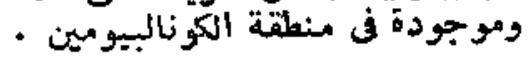

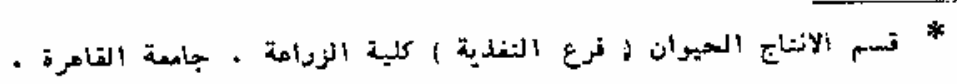

U.A.R. J. Anim. Prod., 11, No. 1 (1971). 